\title{
Ballet er ikke forbi
}

Som indbudt til K\&K-enquêtens damerunde om 'litteraturvidenskaben i dag' skal jeg straks tilstå, at jeg træeder ud på gulvet med en vis tøven. For det første, hvad mere kan der føjes til det panorama over litteraturkritikkens slagmarker og modebølger, som enquêten i K\&K 65-66 allerede så bredt har foldet ud? Risikoen for at lyde som et forsinket ckko af noget som dér er sagt bedre burde sikkert afholde mig. Men for det andet og på den anden side, når man som jeg har deltaget $\mathbf{i}$ en protest til redaktionen over, at der ikke var fundet kvindelige litteraturforskere til enquêtens svarpanel (se K\&K 67), bør man vel ikke sidde en invitation overhørig. Risikoen for at lyde som en fornxrmet bxnkevarmer, der ikke blev budt op til første dans, tilskynder mig til at se bort fra balkort og etikette og opfatte dette mere i stil med det afslappede 'kom-som-duer-party'. Jeg skal blot give mit besyv som den litteraturforsker jeg nu cngang er, ligesom de andre gxster skal give deres.

Marie-Louise Svane er lcktor ved Institut for Litteraturvidenskab, Københavns Universitct.

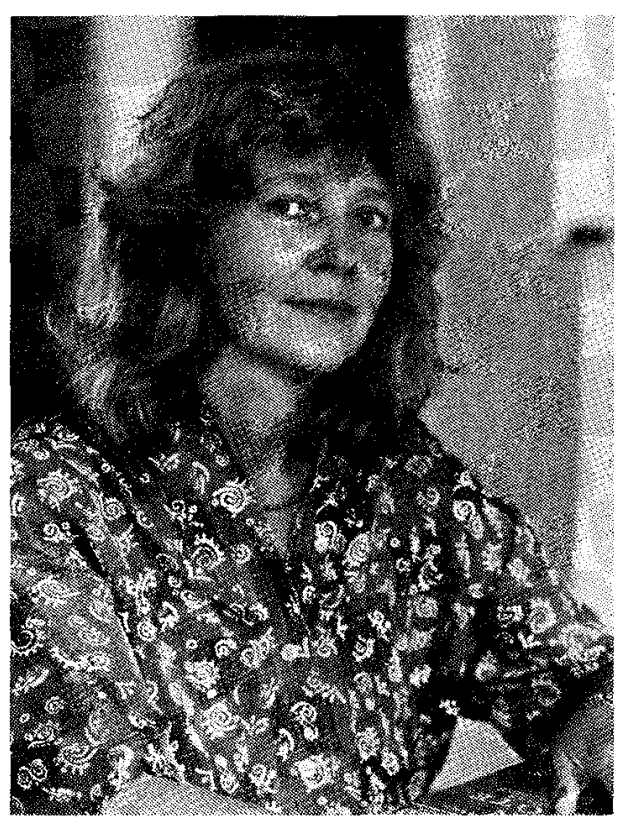


Mens jeg oplivet funderer videre i dette perspektiv, slår det mig imidlertid, at danseassociationerne er out of place, der bliver $i$ hvert fald ikke noget bal af den slags, for de andre gæster er ligesom jeg selv kvinder, måske ligefrem kvindeforskere. Ikke at jeg frygter at kede mig i deres selskab, eller dem i mit, vi er jo intelligente mennesker. Men jeg finder det kedeligt og ude af takt at blive linet op som litteraturkritikkens kvindcfløj, som det forsinkede (fornærmede, retfærdige) feministiske genmæle. Der var engang, da særnumre var på sin plads, men ligesom litteraturforskningen udvikler sig og interesserne spredes, så er der heller ikke nogen fast og blivende fællesbetegnelse for de interesser, som driver forskellige kvinders arbejde med litteraturen og videnskaben. Det næste handler følgelig ikke primært om køin og kvindeforskning, og der cr måske ligefrem en $k \emptyset n s p o l i t i s k$ pointe $i$ at understrege delte.

Efter således skramlende at have sat mig ned og rejst mig fra forskellige stole er jeg trods alt kommet ud på gulvet. Dog har jeg stadig en bemarkning at gøre. Nemlig, at jeg som en slags frihed over for den omtalte enquête-ctikette, vil tillade mig at forholde mig mindre snavert til redaktionens spørgsmål. Jeg vil ikke beskrive litteraturkritikkens situation i dag i karakteriserende langde- eller analyserende tvarsnit. Jeg vil starte med at knytte nogle bemærkninger til et bestemt foredrag, jeg for ikke så långe siden hørte på mit eget institut, institut for litteraturvidenskab, KUA, og som også er optrykt i et tidligerc nummer af nærværende tidsskrift (Kultur og klasse 56). Det drejer sig om min tidligere kollcga, nu professor i massekommunikation i Bergen, Peter

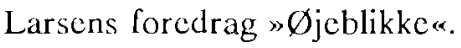

Foredraget handler om Walter Benjamins mediesociologiske essay »Das Kunstwerk im Zcitalter seiner technischen Reproduzicrbarkeit « fra 1936, og jeg vil gerne sige noget om det, fordi jeg opfatter det som typisk på mere end én måde. For det første er det typisk for sin forfatter ved det, at det er godt, skarpt og på mange måder oplysende. Hvilket ikke er det vigtigste, da jeg ikke er ude for at rose eller kritisere Peter Larsen, som klarer sig fint uden mine meninger. Foredraget er nemlig i en anden forstand interessant, finder jeg, fordi jeg ser det som typisk for den litteraturvidenskabelige institution, jeg selv tilhører. Benjamin er et af koryfæerne i de sidste 20 års kulturkritik og litteraturvidenskab, jeg vil f.eks. skyde på at Benjamin er én af de skribenter, der i ct blad som K\&K er skrevct flest henvisninger til. Måske nasst efter Lukàcs, hvis kontrafej toner frem som det eneste 'rigtige' (!) ansigt blandt alle de andre litterære transmutanter på forsiden af K\&Ks enquìte-nunmer (?!)

Benjamin var god i 70'erne, da mange af os prøvede på at vaere gode 
marxister, men hvor nogle af os føltc os en del mere tiltalt af Benjamins sans for at inddrage den bizarre detalje $i$ sin kulturanalyse, end af det store teoretiske hardware af Althusser-formatet. Benjamin er også god i 80'erne og 90'erne, hvor først kapitallogikken er gået sig en tur (uden at jeg har hørt at nogen savner den), og siden også den socialhistoriske intercsse har fået svært ved at holde bastionen og forny sit image med appel til en ny generation af litteraturforskere (jeg undlader her at tale om de ældre generationers blandede følelser for marxisterne). Benjamins appel er, i forhold til så meget andet hot stuff fra 70'erne, langtidsholdbar, sikkert fordi det kritiske perspektiv $\mathrm{i}$ hans analyse indeholder netop så mange momenter af det, som militant blev afvist af 70' $\mathrm{cr}$-marxisterne, selv om det faktisk optog nogle af os mindre militante, og som nu dyrkes med fornyct encrgi hos en ny gruppe af amerikansk orienterede litterater. Jeg tanker på f.cks. refleksionen af de formal-æstetiske træk ved udtrykket cller medict, interessen for oplevelsesmodi hos kultur-recipienten, ja ligefrem beskxftigelse med marginale sindstilstande.

Jeg siger ikke dette for at føre Benjamin i marken som marxismens præfabrikcrede svar på dekonstruktivismen, og såvidt jeg forstår Jan Rosick og Susan Buck-Morss (som var andre foredragsholdere sammen med Peter Larsen ved instituttets Benjamin-scminar) har f.eks. Paul de Man ikke forstået ret meget af Benjamin i sit fors $\emptyset \mathrm{g}$ på en kritisk alliance med sider af Benjamins produktion. Det der interesserer mig her er, at Benjamin ikke er et navn i en modebølge, men snarcre en ever-green, hvis vi skal have ham på plads i K\&K-redaktionens landskabsprospekt over litteraturvidenskaben, dvs. litteraturvidenskaben som den former og slynger sig gennem de sidste godt 20 år. Benjamin citeres hos den litterære venstrefløj dengang og nu, af fcministisk litteraturkritik, i diskussionen om postmodernisme og poststrukturalistisk kritik. Benjamins spændvidde gør, at vi gennem referencen til ham så ofte kommer til at markcre noglc af de underliggende modsatninger, som driver den littcraturkritske diskussion, vi fører p.t. Eller anderledes sagt, spændvidden og spandingerne i Benjamins forfatterskab gør det til et egnet mødested for forskellige litteraturkritiske observanser, og til et sted hvor modstridende analytiske holdninger også støder sammen.

Det er lige her i sammenstødet, Peter Larsen griber fat med sit foredrag » Øjeblikke«, eller han griber den side af Benjamin, som forekommer ham og Brecht, som han citerer i foredraget, uforenclig med den anden, som er den rationelle side, Benjamin som empirisk funderet og marxistisk skolet kulturanalytiker. Den side, Larsen og Brecht tager fat i, den mere dubiøse, er den jeg nævnte ovenfor: Benjamins beskæftigelse 
med kunst-oplevelsen, med mystiske sindstilstande omkring denne, med det som Benjamin udkrystalliserede i sit famøse 'aura'-begreb. Man kan sige, at Brecht ifølge Larsens citat får auraen galt i halsen, han nægter at inhalere den. Mens Peter Larsen, der også er ilde tilmode, dog er nysgerrig nok til at forfølge begrebet minutiøst, skille det ad og finde ud af, hvad der er indeni. Såvidt jeg kan se for lettet at konstatere, at der ikke er noget i det, det er bluff eller overtro, en psykoanalytisk begribelig illusion hos Benjamin, som endvidere hindrer ham i at gennemfore sin analyse af det ikke-auratiske kunstværk, filmen, med tilstrækkeligt køligt overblik og rationel beherskelse af emnet.

Peter Larsen dechiffrerer i essayet to modsatte holdninger til kunstværket, nemlig den auratiske, som er den holdning, der i en særlig forstand identificerer sig med objektet, f.eks. karakteristisk i den kulinariske nydelse (jfr. Brecht) af borgerlig kunst, over for den ikke-auratiske holdning, som er analyscrende, objektiverende, afdækkende, den som finder sagens kerne eller det tomme bluff bag overfladen. Den sidste holdning er tydeligvis den, som Peter Larsen selv praktiserer i sin analyse af Benjamins aura-begreb, og en holdning, som han kun ser Benjamin gennemføre ufuldstændigt i beskæftigelsen med filmmediet. Ultrakort sagt er problemet, at Benjamin lander et forkert sted i sin opfattelse af det nye filmmediums emancipatoriske muligheder. Den filmiske montage og sekvens, filmkameraets dissekerende og isolerende bevægelser ind over filmmotivet forstår Benjamin i første omgang som frigørende, når publikum overtager kameraets analytiske holdning og tranger ind $\mathrm{i}$ virkeligheden. Men dette moment afløses i essayct af Benjamins fokusering på tilskuersubjektets tvungnc overgivelse til billedsekvensens rytme, hans interesse for den fragmenterede oplevelse som et revolutionart xstctisk potentiale. Peter Larsen viser, hvordan Benjamin afskediger den auratisk-identificerende kunstbeskuelse, men ikke til fordel for den aktivt analytiske tilgang til kunstobjcktet, som ligger antydet i essayet, derimod for en astetisk position, der hylder det passive tilskuersubjekts 'spræengning', og som deri kommer betænkelig tæt på det auratiske.

For Peter Larsen demonstrerer dette klart en svaghed hos Benjamin, en blind plet, en form for regressiv passivitet og realitetsuduelighed. Men for sit eget vedkommende kan man sige, at foredragsholderen har løst den opgave, han har stillet sig. Han har viklet det (kun tilsyncladende) indviklede kunstoplevelses-koncept hos Benjamin ud i to overskuelige registre med medierende underregistre mellem en aktiv og en passiv pol, han har med et rask kirurgisk snit skåret ind til tumor, der genererer det syge vav, her: Benjamins fortrængning af den fallisk-sadistiske position. 
Den sidste position, den Larsen kalder fallisk og den Benjamin kalder kirurgisk, er den, der i foredraget identificeres med den rette litteratur-og filmanalytiske holdning, måske ligefrem med en analytisk holdning overhovedet.

Som en litteratur- og billedanalytiker med en anden holdning vil jeg gerne bemarke $\mathrm{i}$ hvertfald tre ting. Og jeg vil indlede med at sige, at hvis læscren her får den opfattelse, at jeg alligevel falder ind $i$ en kønsdiskussion, som jeg sagde ikke var min hensigt, så er det ikke min skyld. Det er Pcter Larsen og ikke mig, der trækker diskussionen op omkring termer som 'fallisk' og 'sadistisk', hvilket naturligvis knyttes til en psykoanalytisk forståelse af positioner i drifts- og kønsudviklingen. Jeg vil ikke kommentere det noget videre, mere fænomenologisk begrænse mig til at se på de forskellige valører af 'gennemboring', 'destruktion' og 'beherskelse', der i forcdraget knyttes til dette falliske. Og jeg afstår ganske fra at se min cgen position som en modsat 'vaginal' litteraturkritisk holdning. Dels føler jeg mig ikke overbevist om modsætningstankningens analytiske fordcle, dels mener jeg ikke, at fænomenerne bliver bedre forståct, fordi de bliver tilordnet en køns-metaforik eller ligefrem en kønsmodsætning.

For det første vil jeg spørge, om ikke en af pointcrne hos Bcnjamin kan være, at der ikke består en sådan lodret modsætning mellem de oplevelscs- og analyscmodi, som Petcr Larsen skanderer frem mcllem et passivt-regressivt-identificcrende registcr og et aktivt-destruktivt-analytisk register. Om denne polaritet evt. ikke mere er et produkt af Pcter Larsens hårdhændede skille-ad-procedure, end ct udsagn $\mathrm{i}$ Benjamins tekst? (Hvilket jeg tør sige uden insinuercn, for det aktivt-destruktive-sadistiske er netop plusordene hos Peter Larsen, det som garanterer det realitetsduclige individ og den akceptable side af medicsociologen Benjamin.) For at sige det på en anden måde, jeg ville ikke vare interesseret $\mathrm{i}$ at redde den 'anden' side af Benjamin, den auratiske, i en slags modspil mod foredraget her. Men snarere i at annullere modsætningen som statisk og cksklusiv. Jcg ville lase efter hos Benjamin for at finde støute for en kritisk holdning, der på cn anden måde blander de nydende og identificerende momenter med en aktiv målrettet og analytisk adfærd over for litteraturen, teksterne, kunstgenstandene, som vi arbejder med.

At nydelse og identifikation indgår som elementer i laseprocessen er vel en banal sandhed. $O g$ at disse processer ikke nødvendigvis er synonyme med at underkaste sig tekstens gode eller dårlige hensigt, forckommer mig lige så indlysende. Det receptivt identificerende og medkonstrucrende forhold lil kunstudtrykket består snarere $\mathrm{i}$ at omfatte det med en forhøjet opmarksomhed, der er åben for 'nye', ikke umiddel- 
bart assimilerbare udsagn, eller som f.eks. registrerer udtrykkets henvisninger til ikke-verbale eller kropserfarede realitcter. Disse måder at træde $\mathrm{i}$ forbindelse med tekster/udtryk på er efter min overbevisning ikke særlig mystiske. Det handler nærmere om at gøre bevidst nogle af de processer, der hele tiden pågår under bevidsthedstærsklen i vores semiotiske omgang med verden, og de kan for min skyld også godt oplyses med henvisning til den psykoanalytiske tale om forskellige libidinøse og aggressive impulser fra den tidlige socialisationsproces, som genaktiveres i mødet med kunstobjektet.

Det vigtige for mig i denne diskussion er, at der ikke kun er tale om forførelse og afmagt, om blokering af mulighed for at forstå, for intellektuelt at tilegne sig viden om. For en udvidet modtagelighed som den angivne, der indlemmer det uassimilerede og de kropslige registre, fjerner mig ikke fra tekstens 'hemmelighed', som jeg destruerende analytisk burde aftvinge den, men den giver mig nogle andre analytiske midler $\mathrm{i}$ hænde. Det er en anden analyseadfærd, der ikke tænker så meget $i$ en overflade-centrum eller fremtrædelses-væsen-model, ikke i kirurgiske snit cller sadistisk voldtægt, men snarere $i$ at manøvrere bchændigt (manipulere, konstruere) i et spektrum af samtidige betydninger, som analysen kan samle op og relatere til forskellige typer kontekst. Overfladen er her ikke kun det dække, detektiven/kirurgen skarer bort for at finde det 'endelige' bevis, men en tekstlig krop cller asstetisk matcrialitet, som kommunikerer betydning af 'uendelig' variation, alt efter hvilke bevagelser analysen foretager.

En anden ting er det, at vi litterater eller kunstforstandige jo hverken er malere eller filmkunstnere, så når Benjamin-Larsen $i$ det omtalte aktiv-passiv-skema skelner filmkameraets kirurgiske operationsgreb fra malerens healer-agtige håndspålæggelse, så behøver vi ikke nødvendigvis at identificere os til én af siderne. Vi har lov at spørge: Bchøver analyse at være at skære i sygt væv? Er teksten syg? Er alternativet til analysen: magi og mangel på dømmekraft?

I litteraturkritikerens job ligger der vel både at kunne forstå, analysere, forklare og bedømme. Og helst ikke det ene uden det andet. Det analytiske greb, hvadenten det skærer eller manipulerer med teksten, er efter min overbevisning ikke den eneste kvalifikation, der kendetegner den 'realitetsduelige' litteraturforsker. På grund af objcktets natur, fordi litteratur, kunst etc. er fiktioner, som ikke udgiver sig for at vare entydig virkelighed, og som følgelig ikke kan beherskes, opereres, helbredes efter samme love som $\emptyset$ konomiske og fysiske tilstande i den samfundsmæessige virkelighed. Teksterne etc. er symbolske realiteter, og det der kvalificerer 
den 'realitctsduclige' litteratur forsker, cr i høj grad også et mere avanceret udstyr end knivsattet, nemlig mere noget ovre i den elektroniske afdeling som f.cks. 'antenner', 'radar', 'ultralydskanner', hvis det endelig skal vare, dvs. forskellige udvidelser af modtagerapparatet.

Det er for det tredje min oplevelse, at en del af dette avancerede udstyr er blevet opbygget hos den yngre generation af dekonstruktions-inspirerede tckstanalytikere, som er i stand til at lave meget mere raffinerede xstcliske analyser og som interesserer sig anderledes for tekst-laser-forholdet, end den ideologikritiske tradition, jeg selv har gåct i skole hos. Angsten for passiv-positionen, som jeg læser ud af Peter Larsens foredrag, og som er gennemgående for hele den marxistiske tradition med dens fokuscring på produktions-aspektet, tror jeg det kunne vere glimrende at slippe for en stund. Det er denne angst, der jager marxisten op fra enhver astetisk fordybelse. Og det var den, der lik Adorno til at forcholde Benjamin, at hans »mikrologiske og ragmentariske metode ikke medtankte »den samfundsmassige totalitetsproces' universale formidling « (i Über Walter Benjamin 1970, s.127-146). Den samme angst genlyder også fra vore dages snart langyarige diskussion om postmodernisme, hvor en marxistisk deltager som Frederic Jameson netop er mest anfagtet ved synet af den sansebombarderede postmoderne mediekonsument, hvis identitet efter hans diagnose bryder sammen i mangel på målretning og i deral følgende handlingslammelse (jfr. f.cks. Jameson, $K \& K 51$ s. 82 ff).

Denne angst for at blive det passive, magtesløse offer for medicindustriens spilleregler refererer sclvfફlgelig til hårde facts om sammenhæenge mellem okonomi, medier og mentalitetsstrukturer i de samfund, vi lever i. Og måske kan man se litteratens situation her i begyndelsen al 90 'erne som én, der på lignende vis bliver sat i en magtesløs rolle. Det arbejde, vi udfører, har ingen synlig samfundsmaessig effekt, bliver end ikke estimeret, der er hverken den sociale nimbus omkring det som måske fordum, cller den furore som på 70'ernes højdepunkt. Tvartimod fortæller den statslige nedskacringspolitik på vores områder os, at vi cr samfundsmassigt overflodige.

Jeg tror, at denne trend er med til at opretholde en vis traditionel jdeologikritisk litteraturholdning, en sammenbidt (mandig?) fornagtelse af magteslesheden, som demonstrerer sin aktive position ved at lægge synlig afstand til en anden litteraturlæsning, der taler om 'dialog' med, 'reception' af teksten etc. Bcskaftigelse med tekstens æstetik, formproblemer, heterogenitet, blandes sammen med magtesløshed og realitetsuduclighed på mange planer.

Walter Benjamin skriver i sit Proust-essay fra 1929 »Zum Bilde 
Prousts«: "Er det rigtigt at sige at alle liv, værker, indsatser af betydning ikke er andet end den uhæmmcde udlevelse af den banalestc, flygtigste, den svageste og mest sentimentale stund $i$ det menneskes eksistens, de knytter sig til?« Her er der tale om overvejelser af form og indhold $\mathrm{i}$ Prousts erindrings-og fiktionaliseringsarbejde $A$ la Recherche du Temps Perdu, som Benjamin går $\mathrm{i}$ dialog med som læeser: "Og da Proust i en berømt passage skildrede denne sin mest private stund, gjorde han det på en sådan måde, at hver og én genkender den fra sin egen tilværelse. Der mangler ikke meget $\mathbf{i}$ at man skulle kalde den dagligdags «. (Min ovs.)

Jeg knytter an til disse bemarkninger hos Benjamin for at vise, hvordan f.eks. i denne tekst dén aktiv/passiv-akse, som Peter Larsen viste i Reproduktions-essayet, her synes at kantre. Det svageste, flygtigste i erfaringen og sansningen slår om $i$ værk og indsats af format. Det passive får aktiv konsekvens, det aktive refererer til det passive. Her er et ekscmpel på Benjamins sensitive opmærksomhed som læser, hans 'mikrologiske metode', når han inddrager det upåfaldende, det uassimilerede $\mathrm{i}$ en kompleks historisk analyse af Proust og forholder det iagttagne til sin egne crfaring. Det er denne Benjamin, jeg synes peger fremad i dagens litteraturdebat, den Benjamin, jeg kunne tænke mig at skrue sammen af de reservedele, som Petcr Larsens foredrag efterlod.

Benjamin er åbenbart rekonstruerbar efter mange formål, og han overlever de fleste nedlagningsforsøg. Der er heller ikke udsigt til at han kommer til at sidde over i de næste runder. Selv tænker jeg på at inklinere. For endelig at få mig en svingom, uden knive i armet, men med godt med rytme og kropskontakt. 